\title{
AOR
}

Selected Papers of \#AolR2020: The $21^{\text {st }}$ Annual Conference of the Association of Internet Researchers Virtual Event / 27-31 October 2020

\section{WATCHING THE WATCHDOG: ONLINE DISCOURSES ABOUT MEDIA FRAUDS}

Tobias Eberwein

Austrian Academy of Sciences / Alpen-Adria-Universität, Vienna, AUSTRIA

\section{Background: Potentials and pitfalls of narrative journalism}

Theoretical and practical justifications of journalistic storytelling stress its potentials for creating a truthful and authentic account of social reality - a necessary prerequisite for journalism in order to live up to its role as a public watchdog (e.g., Schmidt 2019). At the same time, however, narrative approaches to journalism are a regular cause of considerable criticism, particularly when they contribute to blurring the sacred boundaries between fact and fiction (Underwood 2013). Public discussions about the mandate of narrative journalism are often triggered by fraud scandals such as the ones provoked by pseudo-reporters Janet Cooke or Jayson Blair in the U.S., and Tom Kummer or Claas Relotius in the German-speaking world (e.g., Jones Patterson \& Urbanski 2006; Reus 2004). The proposed paper uses the Relotius case as a starting point for a systematic analysis of the responsibility of narrative journalists in an age of "fake news" and post-truth politics - and the question of how they can be held to account in the online realm.

\section{The Relotius case and its implications for Internet research}

For many colleagues, Claas Relotius counted as one of the most talented journalistic storytellers of his generation. He contributed to the most renowned print media in the German-speaking world, most notably to the news magazine Der Spiegel, for which he not only wrote a regular column ("Eine Meldung und ihre Geschichte", engl. "A news item and its story"), but also brought to perfection the so-called reconstructive reportage - a specific narrative genre that has been flourishing in the magazine for at least a decade. In December 2018, aged 33, he received the German "Reporterpreis", the most prestigious national award for narrative journalism, for the fourth time - an unprecedented achievement. Less than three weeks later, it became known that he had fabricated many of his texts, either completely or partly. After admitting his all too careless fusion of fact and fiction, Relotius returned his awards and resigned from his job at the Spiegel. 
Although this revelation developed into one of the biggest German media scandals of the recent years and triggered a massive outcry, also in international media, the case still lacks a systematic analysis from the academic perspective. This deficit is all the more deplorable because the Relotius case could not only contribute to an ethical reflection about the potentials and pitfalls of narrative journalism in the digital age. It also raises the issue of how narrative journalists as public watchdogs can be held to account themselves: While journalistic contents are usually free from direct state control in most democratic societies, the idea of professional self-regulation (e.g. with the help of press and media councils) has become a well-accepted principle of journalistic quality management (e.g., Frost 2000). However, its effectivity is often put into question - not only in the light of recurring fraud scandals (Campbell 1999). Criticism of journalistic self-regulation has paved the way for a discussion of possible benefits of a public social control of journalism in the online realm, e.g. through media watchblogs and critical media observation via social media (Fengler et al. 2014). Until today, however, it is unclear in how far such online instruments of media accountability can really improve the discourse about journalistic quality in a sustainable manner.

\section{Research methods}

The paper attempts to close this research gap with the help of an empirical multimethod study. While an extensive literature review and 13 problem-centered interviews with journalistic storytellers are helpful to highlight and systematize the specific benefits and the ethical challenges of narrative journalism in the German-speaking world and beyond, a comparative analysis of the discourses about the Relotius case in professional journalistic online media, on the one hand, and non-professional media watchblogs, on the other hand, makes it possible to juxtapose different attributions of responsibility and suggested consequences for practical journalism. The discourse analysis covers a time span of twelve months after the revelation of the scandal surrounding Claas Relotius (December 2018 to November 2019) and includes a selection of ten German-language and ten international websites that contributed to the discussion of the case.

\section{Selected results}

The multi-method study allows for a differentiated assessment of web-based media accountability processes in general and the Relotius case in particular:

The review of research from the fields of literary and journalism studies demonstrates that stylistic devices of fiction have a long history in German narrative journalism - and, in many cases, they are an effective means for increasing the truthfulness of journalistic writing. The problem-centered interviews with senior reporters show that Spiegel has used and promoted such techniques for years - most importantly with its concept of the reconstructive reportage. The discourse analysis focusing on the public debate following the revelation of the scandal points out that Spiege/'s editorial board, on the one hand, reacted to the case in a professional manner, by opting for complete transparency in its treatment of the fabrications; on the other hand, however, its reaction also displays a clear lack of self-criticism, because the fictitious techniques that caused Relotius' downfall are - to some extent - common practice in the magazine's narrative pieces. 
Interestingly, the empirical results display clear differences in the online discourses initiated by professional journalists and by non-professional watchbloggers. While many professional commenters prioritize the individual faults of Claas Relotius as a "pathological" liar and primarily recommend reforms on the newsroom level (such as better fact-checking and new ombudsman positions) as a consequence, nonprofessional commenters stress erroneous trends on the macro-level of the journalism system and diverge with regard to recommended measures. A juxtaposition of the professional and non-professional online discourses reveals a bias for both points of view, thus illustrating typical limitations of both journalistic self-regulation and external public control. The results are reflected from a normative perspective and, thus, also contribute to the development of a responsible substantiation of journalistic storytelling beyond popular phrases such as "fake news" and "lying press".

\section{References}

Campbell, A. J. (1999). Self-regulation and the media. Federal Communications Law Journal, 51(3), 711-771.

Fengler, S., Eberwein, T., Mazzoleni, G., Porlezza, C., \& Russ-Mohl, S. (Eds.) (2014). Journalists and media accountability. An international study of news people in the digital age. New York etc.: Peter Lang.

Frost, C. (2000). Media ethics and self-regulation. London: Longman.

Jones Patterson, M., \& Urbanski, S. (2006). What Jayson Blair and Janet Cooke say about the press and the erosion of public trust. Journalism Studies, 7(6), 828-850.

Reus, G. (2004). Mit doppelter Zunge. Tom Kummer und der New Journalism. In Bleicher, J. K., \& Pörksen, B. (Eds.), Grenzgänger. Formen des New Journalism (pp. 249-266). Wiesbaden: VS.

Schmidt, T. R. (2019). Rewriting the newspaper: The storytelling movement in American print journalism. Columbia: University of Missouri Press.

Underwood, D. (2013). The undeclared war between journalism and fiction. Journalists as genre benders in literary history. New York: Palgrave Macmillan. 